\title{
Characterization of an Orthorhombic Crystal Form of Iron-containing Superoxide Dismutase from Escherichia coli B
}

Crystals suitable for X-ray diffraction studies of iron-containing superoxide dismutase from Escherichia coli have been grown using ammonium sulfate as the precipitant. The space group is $P 2_{1} 2_{1} 2_{1}$ with $a=81 \cdot 8 \AA, b=75 \cdot 2 \AA, c=71 \cdot 3 \AA$. A dimer of $M_{\mathrm{r}}=40,000$ occupies the asymmetric unit.

Superoxide dismutases are metalloproteins which catalyze the reaction $2 \mathrm{O}_{2}^{-}+$ $2 \mathrm{H}^{+} \rightarrow \mathrm{O}_{2}+\mathrm{H}_{2} \mathrm{O}_{2}$. These proteins, which have been isolated from both aerobic and strictly anaerobic organisms, require a metal ion for their activity and are readily classified on this basis. Thus eukaryotic cells generally possess two types of superoxide dismutasc, one containing zine and copper, and one having manganese as the essential cofactor. Prokaryotic cells have been found to have both iron and manganesecontaining proteins (Michelson et al., 1977; Beem et al., 1976; Fridovich, 1975).

$\mathrm{X}$-ray crystallographic analysis has yielded a three-dimensional structure for the bovine erythrocyte $(\mathrm{Zn} / \mathrm{Cu})$ superoxide dismutase (Richardson et al., 1975) and work is in progress on the manganese-containing proteins from Escherichia coli and yeast mitochondria (Beem et al., 1976), Bacillus stearothermophilus (Bridgen et al., 1976; Smit et al., 1977) and the iron-containing protein from Pseudomonas ovalis (Yamakura et al., 1976; Petsko, personal communication).

Iron-containing superoxide dismutase from $E$. coli was first isolated by Yost \& Fridovich (1973). A modified procedure (Slykhouse \& Fee, 1976) was used to provide the starting material for the work described here. Crystals were grown at $4^{\circ} \mathrm{C}$ in a hanging droplet containing $10 \mu \mathrm{l}$ of protein solution (5 to $10 \mathrm{mg} / \mathrm{ml}$ in $5 \mathrm{mM}$-phosphate buffer, $\mathrm{pH} 7.5$ ) and $5 \mu \mathrm{l}$ of saturated ammonium sulfate. The siliconized glass coverslip carrying the droplet is sealed with silicone grease over a well containing $0.2 \mathrm{ml}$ of a solution that is $40 \%$ saturated ammonium sulfate and $0.5 \mathrm{M}$-potassium acid phosphate $(\mathrm{pH} 5 \cdot 0)$. A cloudy precipitate develops within a few minutes. Crystals grow within the precipitate and may be observed after two days. In three weeks, five to ten crystals of dimensions suitable for X-ray diffraction measurements $(0.3 \mathrm{~mm} \times$ $0.3 \mathrm{~mm} \times 0.8 \mathrm{~mm}$, and larger) may be harvested from the droplet. These crystals are not visually dichroic. Precession photographs and diffractometer measurements yielded the space group $P 2_{1} 2_{1} 2_{1}$ with unit cell dimensions of $a=81 \cdot 8 \AA, b=75 \cdot 2 \AA$ and $c==71 \cdot 3 \AA$. No other crystal modification has been observed.

Crystal density was measured by the Ficoll gradient procedure described by Westbrook (1976). The observed value of $1.175 \mathrm{~g}$ per $\mathrm{cm}^{3}$ indicates that a dimer of $M_{\mathrm{r}}=40,000$ occupies the asymmetric unit. In addition, a value for $V_{\mathrm{m}}$ (Matthews, 1968) of $2 \cdot 83 \AA^{3} /$ dalton for the dimer is typical of protein crystals. We are currently pursuing the three-dimensional structure of this crystal form. 
We thank Dr $\mathbf{E}$. Westbrook for demonstrating his crystal density measurement technique and determining the value for' the enzyne. 'This work was supported by National Institutes of Health grants GM21519 and GM16429.

Biophysies Research Division Institute of Science \& Technology The University of Michigan 2200 Bonisteel Blvd, Ann Arbor, MI 48109, U.S.A.
Thomas B. Powers

Thomas O. Slykhouse JAMES A. FEE

Martha L. Ludwig

Received 29 March 1978

\section{REFERENCES}

Beem, K. M., Richardson, J. S. \& Richardson, D. C. (1976). J. Mol. Biol. 105, 327-332. Bridgen, J., Harris, J. I. \& Kolb, E. (1976). J. Mol. Biol. 105, 333-335.

Fridovich, I. (1975). Annu. Rev. Biochem. 44, 147-159.

Matthews, B. W. (1968). J. Mol. Biol. 33, 491-497.

Michelson, A. M., MeCord, J. M. \& Fridovich, I. (1977). Editors of Superoxide and Superoxide Dismutases, Academic Press, London.

Richardson, J. S., Thomas, K. A., Rubin, B. H. \& Richardson, D. C. (1975). Proc. Nat. Acad. Sci., U.S.A. 72, $1349-1353$.

Slykhouse, T. O. \& Fee, J. A. (1976). J. Biol. Chem. 251, 5472-5477.

Smit, J. D. G., Pulver-Sladek, J. \& Jansonius, J. N. (1977). J. Mol. Biol. 112, $491-494$.

Westbrook, E. M. (1976). J. Mol. Biol. 103, 659-664.

Yamakura, F., Suzuki, K. \& Mitsui, Y. (1976). J. Biol. Chem. 251, 4792-4793.

Yost, F. J. Jr \& Fridovich, I. (1973). J. Biol. Chem. 248, 4905-4908. 